\title{
TREATABILITY STUDIES OF GROUNDWATER CONTAINING HIGH AMMONIUM CONCENTRATIONS USING CHLORINE BASED COMPOUNDS
}

Ion Viorel Patroescu, Cristiana Cosma, Mihaela Alexie, Lucian Constantin, Ionut Cristea

National Research and Development Institute for Industrial Ecology ECOIND, 71-73 Drumul Podu Dambovitei St., sector 6, Bucharest, Romania tehnologi@incdecoind.ro

\begin{abstract}
The composition of groundwater is of interest for drinking water service providers due to its implications upon the potabilisation treatment flow. The paper is presenting two case studies from Romania, each groundwater sources containing ammonium and organic load reactive to chlorine. Oxidation tests for $\mathrm{NH}_{4}{ }^{+}$were performed using chlorine and sodium hypochlorite on water samples with the following characteristics: $\mathrm{NH}_{4}{ }^{+} \leq 4.4 \mathrm{mg} / \mathrm{L}$ and DOC $<1 \mathrm{mg} / \mathrm{L}$. Oxidation tests with chlorine at the breakpoint showed that a weight ratios of $\mathrm{Cl}_{2}$ $: \mathrm{N}^{-\mathrm{NH}_{4}}{ }^{+} \geq 10: 1$ and reaction time of $40 \mathrm{~min}$ are needed in order to assure a remanent concentration of $\mathrm{NH}_{4}{ }^{+}$below the admissible value of $0.5 \mathrm{mg} / \mathrm{L}$, residual chlorine concentrations being in the range of $12-20 \mathrm{mg} / \mathrm{L}$, and THM concentration after $24 \mathrm{~h}$ in the range of $102-277 \mu \mathrm{g} / \mathrm{L}$. Oxidation tests with $\mathrm{NaOCl}$ showed that even at high doses of active chlorine $(30 \mathrm{mg} / \mathrm{L})$ and long reaction time of $24 \mathrm{~h}$, remanent ammonium concentration is higher than the admissible value of $0.5 \mathrm{mg} / \mathrm{L}$, residual chlorine concentration being of $\mathrm{mg} / \mathrm{L}$ order. In this case, selection of an alternative raw water source or the replacement of classical oxidation technology using chlorine by biological nitrification is needed.
\end{abstract}

Keywords: ammonium, chlorinated by-products, groundwater, natural organic matter

\section{Introduction}

The main usage of chlorine in drinking water treatment is for disinfection (preand post disinfectant). However, chlorine has also found application for a variety of other water treatment objectives, such as: oxidation of iron, manganese, hydrogen sulfide, ammonia, prevention of algal growth in sedimentation basins and filters, maintenance of biological stability of drinking water by prevention of bacteria regrowth in the distribution system [1].

In Romania, the treatment technologies currently applied for $\mathrm{N}_{-} \mathrm{NH}_{4}{ }^{+}$oxidation involve use of chlorine, the only chemical oxidant which can react with $\mathrm{NH}_{4}{ }^{+}$ ions at the $\mathrm{pH}$ current values of natural drinking water resources, ground water especially.

The use of chlorine in order to reduce $\mathrm{NH}_{4}{ }^{+}$concentration is based on the oxidation reactions to elemental nitrogen, the intermediates compounds being the chloramines (mono-, di-, chloramines and nitrogen trichloride).

The stoichiometric ratio chlorine to nitrogen ammonia $\left(\mathrm{Cl}_{2}: \mathrm{N}^{-\mathrm{NH}_{4}}{ }^{+}=7.6: 1\right)$ assuring $\mathrm{N}_{2}$ as major end product is not affected by $\mathrm{pH}$, the ideal operating 
values for break point chlorination being situated between $\mathrm{pH}=7$ and $\mathrm{pH}=8$. Taking into account the variability of groundwater pollution matrices, the chlorine demand for $\mathrm{N}^{-\mathrm{NH}_{4}+}$ break point chlorination is determined by experimental works for each case, the variation domain of $\mathrm{Cl}_{2}: \mathrm{N}^{-\mathrm{NH}_{4}+}$ weight ratio being quite large $\left(\mathrm{Cl}_{2}: \mathrm{N}-\mathrm{NH}_{4}{ }^{+}=7.6: 15 / 1\right)$.

Numerous inorganic and organic pollutants/micropollutant can undergo reaction with chlorine, for most of them $\mathrm{HOCl}$ being the major reactive chlorine specie. Natural organic matter (NOM) like humic substances present in water resources react with aqueous free chlorine or free bromine, halogenated by-products being formed. Several factors such as: $\mathrm{pH}$, dissolved organic carbon (DOC), bromide concentration, temperature and operational factors like chlorine dose, contact time were reported to affect the formation of halogenated by-products.

Aqueous chlorine converts bromide ion to hypobromous acid, which can react with organic matter in the same way as hypochlorous acid to form various bromchlorinated by-products, $\mathrm{HOBr}$ being a stronger halogenating agent than $\mathrm{HOCl}$. THM species $\left(\mathrm{CHCl}_{3}, \mathrm{CHBrCl}_{2}, \mathrm{CHBr}_{2} \mathrm{Cl}, \mathrm{CHBr}_{3}\right)$ were proven to have adverse effects on human health, especially brominated species being suspected to be much stronger carcinogens and mutagens than nonbrominated species.

Only a small percentage of chlorinated by-products has been quantified/regulated in drinking water: THMs, the MCL total THM being 80 / 100 $\mu \mathrm{g} / \mathrm{L}$ (US regulations / EU regulations).

The other by-products reported for treated water using chlorine (oxidation / disinfection reaction) are, as follows: haloacetic acids (HAAS/MCL $=60 \mu \mathrm{g} / \mathrm{L}$ only in US regulations), haloacetonitriles (HANS), haloketones, haloaldehydes

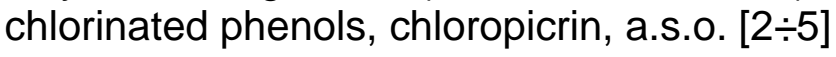

\section{Materials and Methods}

The aim of experimental tests was to demonstrate how the chlorination process applied for the treatment of groundwater containing $\mathrm{N}-\mathrm{NH}_{4}{ }^{+}$ions higher than 1 $\mathrm{mg} / \mathrm{L}$, and low natural organic matter $(\mathrm{TOC}<1 \mathrm{mgC} / \mathrm{L})$ can affect the quality of drinking water.

The following experimental activities were performed:

- Analytical investigation of two groundwater sources (200-340 m depth) in order to evaluate the main quality parameters: $\mathrm{pH}$, turbidity, hardness, conductivity, ammonia, COD-Mn, TOC/DOC, inorganic ions ( $\mathrm{Fe}, \mathrm{Mn}$ ), bromide ion;

- Assessment of THM potential formation (THMPF), due to the reactivity of NOM towards chlorine in specific conditions $\left(\mathrm{Cl}_{2}\right.$ doses, $\mathrm{pH}$, reaction time, temperature). Periodically, determination of generated THMs along the experimental period (7 days) was done;

- Oxidation of ammonium ion by using chlorine based compounds $\left(\mathrm{Cl}_{2}\right.$, $\mathrm{NaClO}$ ) in specific conditions as follows:

- $\mathrm{N}-\mathrm{NH}_{4}{ }^{+}$break-point chlorination

- $\mathrm{Cl}_{2}: \mathrm{N}_{-} \mathrm{NH}_{4}{ }^{+}=10 / 15: 1$ (weight ratio)

- reaction/contact time $=40$ minutes $/ 24$ hours

Chlorine water $\left(\mathrm{Cl}_{2}=0.9-1 \mathrm{~g} / \mathrm{L}\right)$ was used as chlorine source. 
Analysed parameters after $40 \mathrm{~min} / 24$ hours reaction time were: $\mathrm{pH}$, residual $\mathrm{NH}_{4}{ }^{+}$, residual $\mathrm{Cl}_{2}$ (total and free), THMs.

\section{- $\mathrm{NH}_{4}{ }^{+}$oxidation using $\mathrm{NaClO}$}

- $\mathrm{Cl}^{*}$ (active chlorine) doses $10 \div 30 \mathrm{mg} \mathrm{Cl}^{*} / \mathrm{L}$

- reaction/contact time $=40$ minutes/24 hours

$\mathrm{NaClO}$ solution $\left(1.84 \mathrm{~g} \mathrm{Cl}^{*} / \mathrm{L}\right.$ ) was used as chlorine source.

Analysed parameters after 40 minutes/24 hours reaction time were: $\mathrm{pH}$, residual $\mathrm{NH}_{4}^{+}$, residual $\mathrm{Cl}_{2}$ (total and free)

Analytical investigations for raw/treated groundwater characterization were performed using standardized methods.

\section{Results and Discussion}

\section{Assessment of groundwater quality}

The analytical investigations emphasized the main pollutants which are situated above the $\mathrm{MCL}$ values $\left(\mathrm{NH}_{4}{ }^{+}\right.$, turbidity/Fetotal) or can influence the generation of THMs (TOC/DOC, $\mathrm{Br}^{-}$). According to the registered data (Table 1), the following remarks are:

- $\mathrm{NH}_{4}{ }^{+}$concentrations are rather high, around $4 \mathrm{mg} / \mathrm{L}$ $\left(\mathrm{MCL}_{\mathrm{NH}_{4}^{+}}=0.5 \mathrm{mg} / \mathrm{L}\right)$;

- Turbidity values are also higher than MCL $\leq 5 \mathrm{NTU}$, due to the presence of iron hydroxide (Feprecipided $\leq 800 \mu \mathrm{g} / \mathrm{L}$ );

- Organic load evaluated as total organic/dissolved organic carbon (TOC/DOC) is situated below $1 \mathrm{mg} \mathrm{C} / \mathrm{L}(<0.5 \mathrm{mg} / \mathrm{L})$, majority of $\mathrm{NOM}$ being under dissolved form (91-95\%);

- $\mathrm{Br}^{-}$ion, not normed by specific law for drinking water quality, is below the detection limit of method $\left(\mathrm{Br}^{-}<100 \mu \mathrm{g} / \mathrm{L}\right)$.

Table 1. Main physical-chemical characteristics of groundwater located in Targu-Jiu county: P1 and P2 (momentary samples)

\begin{tabular}{|l|c|c|c|}
\hline \multirow{2}{*}{ Parameter } & \multirow{2}{*}{ U.M. } & \multicolumn{2}{c|}{ Values } \\
\cline { 3 - 4 } & & P1 & P2 \\
\hline $\mathrm{pH}$ & - & 7.7 & 8.2 \\
\hline $\mathrm{COD}-\mathrm{Mn}$ & $\mathrm{mgO} / \mathrm{L}$ & 2.2 & 1.5 \\
\hline TOC/DOC & $\mathrm{mgC} / \mathrm{L}$ & $0.41 / 0.39$ & $0.34 / 0.31$ \\
\hline Turbidity & $\mathrm{NTU}$ & 13.5 & 19 \\
\hline Total hardness & German degree & 21 & 1.3 \\
\hline Conductivity & $\mu \mathrm{S} / \mathrm{cm}$ & 1005 & 361 \\
\hline Fe total & $\mu \mathrm{g} / \mathrm{L}$ & 660 & 838 \\
\hline Fe dissolved & $\mu \mathrm{h} / \mathrm{L}$ & 14 & $<0.2$ \\
\hline $\mathrm{Mn}$ total $^{\mathrm{Mn} \text { dissolved }}$ & $\mu \mathrm{g} / \mathrm{L}$ & 33 & 24 \\
\hline $\mathrm{NH}_{4}{ }^{+}$ & $\mu \mathrm{g} / \mathrm{L}$ & 28 & 17 \\
\hline $\mathrm{Br}^{-}$ & $\mathrm{mg} / \mathrm{L}$ & 4.2 & 4.35 \\
\hline
\end{tabular}


Assessment of THM potential formation (THMPF)

The applied chlorine doses where in accordance with DOC and $\mathrm{N}^{-\mathrm{NH}_{4}}{ }^{+}$ concentrations for each sources, the work conditions being similar: $\mathrm{Cl}_{2}$ : DOC ratio $=3: 1, \mathrm{Cl}_{2}: \mathrm{N}-\mathrm{NH}_{4}{ }^{+}$ratio $=8.1: 1$, contact time $1 \div 7$ days, buffered $\mathrm{pH}=$ $7-7.2$, temperature $20-22{ }^{\circ} \mathrm{C}$.

The evolution of THMs concentrations and residual chlorine (total/free) in time is presented in figures 1-2. Also, the speciation of THMs for the first and last day of tested period is presented in the figures 3.1, 3.2.

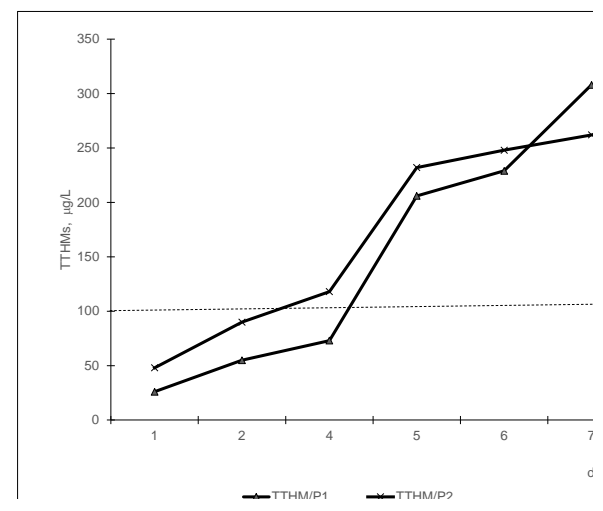

Figure 1. THMPF - Evolution of THMs concentrations vs contact time

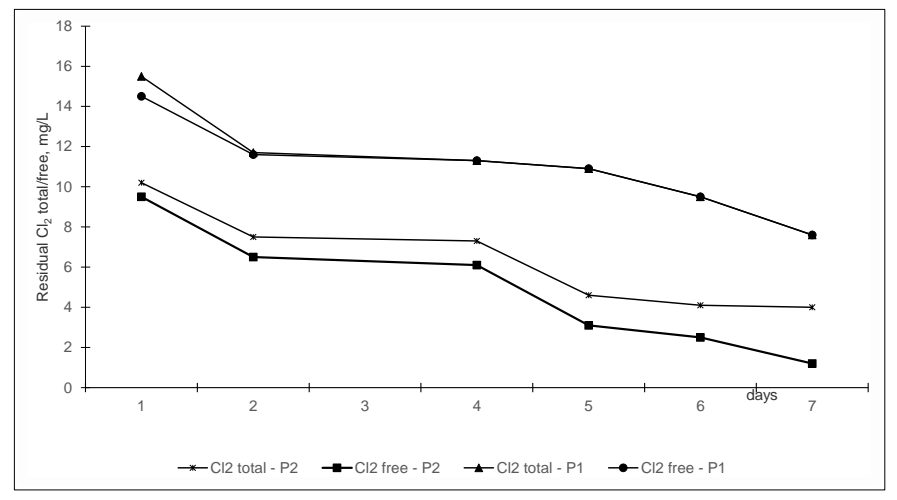

Figure 2. THMPF - Evolution of residual chlorine

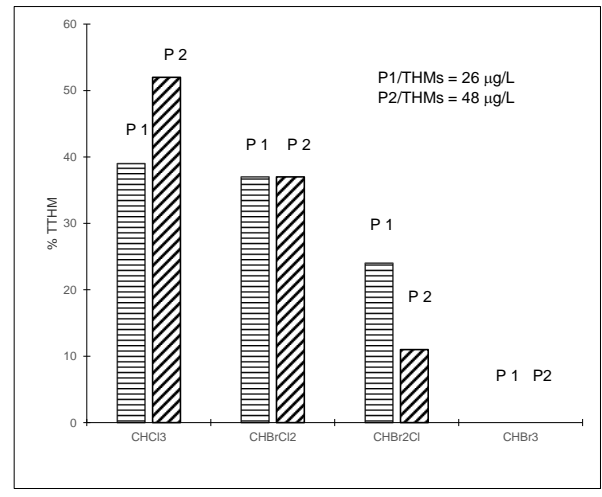

Figure 3.1. THMPF - THMs speciation (day 1) 


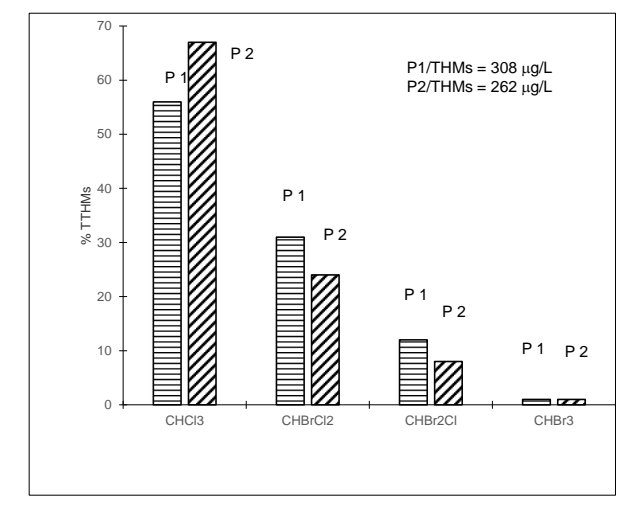

Figure 3.2. THMPF - THMs speciation (day 7)

The following aspects are resulting taking into account the experimental results:

- TTHMs generated in the two groundwater sources (P1, P2) present an increasing evolution in time, proving the reactivity of dissolved organic matter $(\mathrm{DOC}=0.31-0.39 \mathrm{mg} \mathrm{C} / \mathrm{L}$ ) toward chlorine and in situ generated bromide. According to the literature data, "high DOC" concentration value, potential to produce THMs higher than MCL $(100 \mu \mathrm{g} / \mathrm{L})$ is situated above $2 \mathrm{mg} \mathrm{C} / \mathrm{L}$. But, the presence of high concentrations of associated pollutants such as ammonium ion $\left(\mathrm{NH}_{4}{ }^{+} \simeq 4 \mathrm{mg} / \mathrm{L}\right)$, which need high doses of chlorine for oxidation the organic/inorganic THMs precursors $\left(\mathrm{DOC} / \mathrm{Br}^{-}\right)$can generate halogenated by-products in watery system.

- Taking into acount the low concentration of DOC ( $<0.5 \mathrm{mg} \mathrm{C/L}$ ), the generated THMs are exceeded the MCL value only after 4/5 days (fig. 1 ).

So, TTHMs after 1-2 days are situated below MCL, between $55 \mu \mathrm{g} / \mathrm{L}$ (P1) and $90 \mu \mathrm{g} / \mathrm{L}$ (P2) the generated species being $\mathrm{CHCl}_{3}(54-55 \%)$ and brominated derivates (45-46\%), fig. 3.1.

- The final TTHMs concentrations (contact time $=7$ days) are two/three times higher than MCL (P1/THMs $=308 \mu \mathrm{g} / \mathrm{L} ; \mathrm{P} 2 / \mathrm{THMs}=262 \mu \mathrm{g} / \mathrm{L})$, the main generated specie being $\mathrm{CHCl}_{3}\left(\mathrm{P}_{1} / \mathrm{CHCl}_{3}=56 \%\right.$ TTHMs, $\mathrm{P} 2 / \mathrm{CHCl}_{3}=67 \%$ TTHMs).

The total bromited derivates $\left(\mathrm{CHCl}_{2} \mathrm{Br}, \mathrm{CHClBr}, \mathrm{CHBr}_{3}\right)$ are representing $44 \%(\mathrm{P} 1)$ and $33 \%(\mathrm{P} 2)$ of final TTHMs, which confirm the influence of bromide ion even at low concentration (B $\left.r^{-}<100 \mu \mathrm{g} / \mathrm{L}\right)$ upon THM speciation (fig. 3.2).

- Total residual chlorine concentration is decreasing in time (fig. 2).

\section{Assessment of ammonium ion break point chlorination}

The use of chlorine, the only chemical oxidant which can react with $\mathrm{N}^{-\mathrm{NH}_{4}}{ }^{+}$, (break point chlorination), generates as reaction products, chloramines as intermediates and elemental nitrogen $\left(\mathrm{N}_{2}\right)$.

The experimental results of chlorination testes performed in order to reduce ammonium ion concentrations below $\mathrm{MCL}(0.5 \mathrm{mg} / \mathrm{L})$ by applying high $\mathrm{Cl}_{2}$ : $\mathrm{N}-\mathrm{NH}_{4}{ }^{+}$ratios $(10 / 15: 1)$ are presented in the table 2. 
Table 2. $\mathrm{NH}_{4}+$ break point chlorination. Influence of $\mathrm{Cl}_{2}: \mathrm{N}-\mathrm{NH}_{4}+$ ratio

\begin{tabular}{|c|c|c|c|c|c|c|}
\hline \multirow{3}{*}{$\mathrm{Cl}_{2}: \mathrm{N}-\mathrm{NH}_{4}{ }^{+}$ratio } & \multicolumn{6}{|c|}{ Treated water. Residual concentrations } \\
\hline & \multicolumn{2}{|c|}{$\begin{array}{l}\mathrm{NH}_{4}^{+}, \\
\mathrm{mg} / \mathrm{L}\end{array}$} & \multicolumn{2}{|c|}{$\begin{array}{c}\text { Free } \mathrm{Cl}_{2} / \\
\text { Combined } \mathrm{Cl}_{2}, \mathrm{mg} / \mathrm{L}\end{array}$} & \multicolumn{2}{|c|}{$\begin{array}{c}\text { TTHMs, } \\
\mu \mathrm{g} / \mathrm{L}\end{array}$} \\
\hline & P 1 & P 2 & P1 & P 2 & P 1 & P 2 \\
\hline $10: 1$ & & \multirow[t]{2}{*}{0.48} & \multirow[t]{2}{*}{$11 / 1$} & \multirow[t]{2}{*}{$15 / 2.5$} & $4.3 / 40 \mathrm{~min}$ & $11.7 / 40 \mathrm{~min}$ \\
\hline \multirow[b]{2}{*}{$15: 1$} & & & & & $\frac{102 / 24 \mathrm{~h}}{18 / 10 \mathrm{~min}}$ & $\frac{250 / 24 \mathrm{~h}}{155 / 40 \mathrm{~min}}$ \\
\hline & 0.32 & 0.12 & $12 / 2.5$ & $19 / 1$ & $220 / 24 \mathrm{~h}$ & $277 / 24 \mathrm{~h}$ \\
\hline \multicolumn{5}{|c|}{$\begin{array}{l}\text { Raw water } \\
\text { P1: } \mathrm{pH}=7.54 ; \mathrm{NH}_{4}+=4.2 \mathrm{mg} / \mathrm{L} \\
\mathrm{P} 2: \mathrm{pH}=8.2 ; \mathrm{NH}_{4}{ }^{+}=4.35 \mathrm{mg} / \mathrm{L}\end{array}$} & \multicolumn{2}{|c|}{$\begin{array}{c}\text { Work condition } \\
\mathrm{Cl}_{2}: \mathrm{N}-\mathrm{NH}_{4}{ }^{+}=(10 \div 15): 1 \\
\tau \text { oxidation }=40 \text { minutes } \\
\mathrm{pH}=7-7.2\end{array}$} \\
\hline
\end{tabular}

The following remarks are emphasized:

- $\mathrm{NH}_{4}{ }^{+}$residual concentration decreasing with applied $\mathrm{Cl}_{2}$ doses, $\mathrm{NH}_{4}{ }^{+}$ values below MCL for both treated water samples (P1 and P2) being registered for $\mathrm{Cl}_{2}: \mathrm{N}^{-\mathrm{NH}_{4}+}=15: 1$;

- high residual chlorine free and combined concentrations $(\mathrm{mg} / \mathrm{L})$ in treated water after 40 minutes of contact/reaction above MCL;

- slow increase of THMs in treated water after 40 minutes of reaction (P1/THMs $<5 \mu \mathrm{g} / \mathrm{L} ; \mathrm{P} 2 / \mathrm{THMs}<16 \mu \mathrm{g} / \mathrm{L}$ ) for both chlorine doses;

- development in time of specific chlorinating reactions (oxidation, substitution) with the increase of THMs above MCL after 24 hours (P1/THMs $\leq 220 \mu \mathrm{g} / \mathrm{L} ; \mathrm{P} 2 / \mathrm{THMs} \leq 277 \mu \mathrm{g} / \mathrm{L})$.

\section{Assessment of ammonium ion oxidation using $\mathrm{NaClO}$}

In Romania a large number of DTWPs for small communities (raw watergroundwater) is using sodium hypochlorite $(\mathrm{NaClO})$ for water disinfection and also for specific pollutants oxidation $\left(\mathrm{NH}_{4}{ }^{+} \pm \mathrm{NO}_{2}{ }^{-} \pm \mathrm{S}^{2-} \pm \mathrm{Mn}^{2+}\right)$.

The reaction between $\mathrm{NaClO}$ (solution, typically with $12.5 \%$ available chlorine) and water: $\mathrm{NaClO}+\mathrm{H}_{2} \mathrm{O} \rightarrow \mathrm{HClO}+\mathrm{Na}^{+}+\mathrm{HO}^{-}$releases hydroxyl ions that will increase the $\mathrm{pH}$ of water.

The aim of experimental tests was to evaluate the reactivity of $\mathrm{NaClO}$ towards $\mathrm{NH}_{4}{ }^{+}$ions, the applied doses being between 10 and $30 \mathrm{mg} \mathrm{Cl} / \mathrm{L}$, at contact/reaction time of 40 minutes and 24 hours.

The influence of applied doses at contact/reaction time of 40 minutes is presented in the figure 4, also the influence of contact time was evaluated (Table 3) 


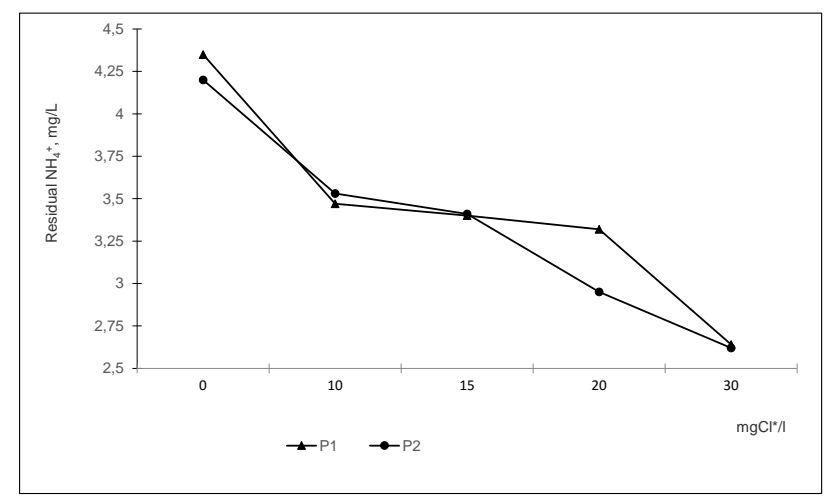

Figure 4. $\mathrm{NH}_{4}{ }^{+}$oxidation using $\mathrm{NaClO}$. Influence of oxidant dose (contact time $=$ 40 minutes)

Table 3. $\mathrm{NH}_{4}{ }^{+}$oxidation using $\mathrm{NaClO}$. Influent of contact / reaction time

\begin{tabular}{|c|c|c|c|c|c|c|c|c|}
\hline \multirow[t]{3}{*}{ Parameter } & \multicolumn{4}{|c|}{$20 \mathrm{mg} \mathrm{Cl}^{*} / \mathrm{L}$} & \multicolumn{4}{|c|}{$30 \mathrm{mg} \mathrm{Cl} / \mathrm{L}$} \\
\hline & \multicolumn{2}{|c|}{$\tau=40 \mathrm{~min}$} & \multicolumn{2}{|c|}{$\tau=24 \mathrm{~h}$} & \multicolumn{2}{|c|}{$\tau=40 \min$} & \multicolumn{2}{|c|}{$\tau=24 \mathrm{~h}$} \\
\hline & P1 & P 2 & P 1 & P 2 & P 1 & P 2 & P1 & P 2 \\
\hline $\mathrm{pH}$ & 8.14 & 8.3 & 8.12 & 8.1 & 8.15 & 8.35 & 8.14 & 8.20 \\
\hline $\mathrm{NH}_{4}{ }^{+}, \mathrm{mg} / \mathrm{l}$ & 3.36 & 2.95 & 2.02 & 1.5 & 2.64 & 2.62 & 1.33 & 1.2 \\
\hline $\begin{array}{l}\text { Total residual } \\
\mathrm{Cl}_{2} / \text { Free } \mathrm{Cl}_{2}\end{array}$ & $8.4 / 0.1$ & $9.1 / 0.1$ & $3 / 0.1$ & $2.7 / 0.1$ & $10 / 0.1$ & $10.1 / 0.1$ & $3.4 / 0.1$ & $3.2 / 0.1$ \\
\hline & & $\begin{array}{l}\text { P1: } \\
\text { P2: }\end{array}$ & & $\begin{array}{l}\text { aw v } \\
\mathrm{NH}_{4} \\
\mathrm{NH}_{4}+\end{array}$ & & & & \\
\hline
\end{tabular}

According to experimental results the following aspects are emphasized:

- Oxidation yields of $\mathrm{NH}_{4}{ }^{+}$are depending on oxidant applied dose, a slow increasing being registered $(P 1=17-37 \% ; P 2=14-36 \%)$.

- The increasing of contact/reaction time at 24 hours leads to the improvement of oxidation efficiences $\left(\eta \mathrm{NH}_{4}{ }^{+} \leq 71 \%\right)$, but the $\mathrm{NH}_{4}{ }^{+}$ residual concentrations are situated above $\mathrm{MCL}\left(\mathrm{P} 1 / \mathrm{NH}_{4}{ }^{+}=1.33 \mathrm{mg} / \mathrm{L}\right.$; $\left.\mathrm{P} 2 / \mathrm{NH}_{4}{ }^{+}=1.2 \mathrm{mg} / \mathrm{L}\right)$.

- The residual chlorine $(\mathrm{mg} / \mathrm{L})$ is majority under combined forme.

\section{Conclusion}

In Romania, the treatment technologies currently applied for ammonium ions oxidation involve use of chlorine based compounds $\left(\mathrm{Cl}_{2} / \mathrm{NaClO}\right)$. The experimental tests performed in order to verify the process aplicability for the treatment of groundwater containing $\mathrm{NH}_{4}{ }^{+}>1 \mathrm{mg} / \mathrm{L}$ and organic natural matter $(\mathrm{DOC}<0.5 \mathrm{mg} / \mathrm{L})$ leads to the following conclusion:

$>$ high doses of chlorine required by $\mathrm{N}-\mathrm{NH}_{4}{ }^{+}$break point chlorination $\left(\mathrm{Cl}_{2}: \mathrm{N}-\mathrm{NH}_{4} \geq 10: 1\right)$ are able to affect the quality of treated water;

$>$ the noncompliance aspects related to the treated water intended to human consumption (THMs concentration, residual chlorine free and combined chlorine ratio a.s.o.) impose the replacement of classic process based on chemical oxidation with other process (biological nitrification). 


\section{References}

[1] EPA, Alternatives Disinfectants and Oxidants, Guidance Manual (1999), United States, Environmental Protection Agency, Office of Water, 1/5, 2/18-22.

[2] Deborde M. von Gunter U. (2008), Reaction of Chlorine with Inorganic and Organic Compounds During Water Treatment - Kinetics and Mechanism: A critical review, 42, 13-51.

[3] Chuan T., Ruiping L., Huijuan L., Jiuhui W., (2013), Disinfection Byproducts Formation and Precursors Transformation During Chlorination and Chloramination of Highly-Polluted Source Water: Significance of Ammonia, Water Research, 47(16), 5901-5909.

[4] Cosma C., Nicolau M., Patroescu V., Stefanescu M., Ballo A., Florescu S., (2009), The Incidence of By-products (THMs) Disinfection in Drinking Water, Journal of Environmental Protection and Ecology, 1, 14-22.

[5] Patroescu V., Jinescu C., Cosma C., Cristea I., Badescu V., Stefan C.S., (2015), How Ammonium lons can Influence the Treatment Process Selection of Groundwater Supplies Intended to Human Consumption, Revista de Chimie, 66(4), 537-541 